\title{
Knowledge on Batik and Lifestyle on Purchase Decisions with Satisfaction as Intervening (Case Study of Batik SME'S in Jambi City)
}

\section{R. Adjeng Mariana Febrianti ${ }^{1 *}$, Sriwardani ${ }^{2}$, Fitrizal Eko Warnadi ${ }^{3}$, Mediyona Samba Saleh ${ }^{4}$}

Widyatama University, Bandung Indonesia

1*adjeng.mariana@widyatama.ac.id,_25riwardani@unla.ac.id,_ 3 fitrizal.warnadi@widyatama.ac.id,

${ }^{4}$ mediyona.samba@widyatama.ac.id

Article History: Received:11 January 2021; Accepted: 27 February 2021; Published online: 5 April 2021

\begin{abstract}
The purpose of this study was to determine the effect of consumer knowledge and lifestyle on purchasing decisions with customer satisfaction as an intervening variable. The method used in this research is path analysis method. The sample used was 118 respondents. While data collection by means of a questionnaire. The results showed that knowledge has a positive and significant influence on purchase intention with tcount $6,066>$ ttable 1,984 and sig value $0,000<0.05$. Lifestyle has a positive and significant influence on purchase intention with a tcount of 3.952> ttable of 1.984 and a sig value of $0.000<0.05$. Consumer satisfaction has a positive and significant influence on purchasing decisions with a tcount of 3.902> ttable 1.984 and a sig value of $0.002<0.05$. Consumer knowledge has a positive and significant influence on purchasing decisions with a $t-$ count value of 4.987> t-table 1.984 and a sig value of $0.000<0.05$. Lifestyle has a positive and significant effect on purchasing decisions with a tcount of $2.531>$ ttable 1.984 and a sig value of $0.013<0.05$. Consumer satisfaction is able to mediate the effect of trust on purchasing decisions as evidenced by the sobel test results 2.492> 1.96. satisfaction is able to mediate the effect of promotion on purchasing decisions as evidenced by the sobel test results 2.77> 1.96. The conclusion from this research is that the higher the level of consumer knowledge, the higher the satisfaction and purchasing decisions.
\end{abstract}

Keywords: Knowledge, lifestyle, purchasing decisions, satisfaction

\section{Introduction}

Batik in Indonesia is estimated to have started and developed in the Hindu era, especially in the aristocratic family and the palace, this is reinforced by the discovery of batik motifs on relief carvings, statues that adorn temples. The use of batik cloth is very limited for the purposes of aristocratic clothing, and for ritual purposes related to beliefs and beliefs. However, over time batik was used not only as a royal (aristocratic), society in general had also known batik. In its development, batik has a social impact on every region in Indonesia. Each region shows its style, identity, uniqueness, and uniqueness in each batik production. So that it gives rise to differences in batik products from one region to another. Every batik has a meaning and meaning as well as a philosophy that underlies the creation of a motif, society interprets the batik motif as a form of identity, elements and a beautiful basis that describes its environment.

Meanwhile, as the provincial capital, the city of Jambi has the potential to drive the community's economy. There are various types of SME'S that have developed in Jambi city. One type of MSE that is developing in the city of Jambi is the Jambi batik SME'S. The Seberang area of Jambi city is the center for the development of Jambi batik SME'S in Jambi province. It is undeniable that Batik from the city of Jambi also confirms batik as a world cultural heritage from Indonesia. Jambi batik does have its own allure, among other things, from the sharp coloring technique, the coastal characteristics seen in the motifs that bring out marine elements, such as fish scales, shells, or seaweed tendrils. On a sheet of cloth, contrasting colors can appear that are not found in inland or coastal batik fabrics in Java. Jambi batik is very expressive; it can be seen from the dominant graffiti depicting the freedom of expression of the batik craftsmen in pouring their imagination on a piece of batik cloth. A small portion of the people of Jambi city still adhere to the cultural heritage that refers to the rules / regulations, although it is gradually being abandoned.

The lifestyle of consumers is one of the factors that can reduce the buying interest in batik, especially the city of Jambi. Likewise, with consumer knowledge of the quality of batik itself which is a factor in purchasing decisions. Therefore, this study tries to determine the effect of knowledge and lifestyle on purchasing decisions with customer satisfaction as an intervening variable. As for the formulation of the problem in this study are:

1. Does consumer knowledge have a significant effect on customer satisfaction?

2. Does the consumer's lifestyle have a significant effect on customer satisfaction?

3. Does consumer knowledge influence consumer purchasing decisions? 
4. Does lifestyle influence consumer purchasing decisions?

5. Does consumer knowledge and lifestyle influence consumer purchasing decisions through customer satisfaction?

\section{Theoritical Review}

\subsection{Knowledge}

According to Paschen et al. (2019), knowledge is a treasure trove of mental wealth which directly or indirectly enriches our lives. Each type of knowledge basically answers a certain type of question that is asked. The knowledge of a person with other people is different, so that knowledge is a mental wealth that directly or indirectly enriches human life (Rauch \& Patrick, 2016). In another sense, knowledge is a variety of symptoms that humans encounter and acquire through the observation of reason (Dierh, 2017). Knowledge arises when someone uses their mind to recognize certain objects or events that have never been seen or felt before (Chukwuma, 2018). Changes in the subject's behavior to the product start from the subject knowing and knowing the product first, then the subject begins to be interested in the product, after that the subject begins to weigh the advantages and disadvantages of the product against himself, then the subject starts trying, and finally the subject makes a customized purchase with knowledge, awareness and attitude towards products (Chen \& Huang, 2010) According to Aydiner (2019), there are six deep level domains, knowledge, understanding, application, analyst, synthesis, and evaluation. According to Kotler (2017), there are four dimensions in explaining knowledge variables, namely, (1) factual knowledge, (2) conceptual knowledge, (3) procedural knowledge, (4) metacognitive knowledge.

\subsection{Lifestyle}

According to Kotler and Keller (2017), consumers make their decisions not in an isolated place from the surrounding environment. Their voting behavior is strongly influenced by cultural, social, personal, personal and psychological factors (Rakic, 2015). And from the personal factors of the consumer's lifestyle that influence his decision in choosing a product. Kotler (2017) argues that the notion of lifestyle as a lifestyle is a person's lifestyle in the world which is expressed in their activities, interests and opinions. Lifestyle shows a person's whole self in interacting with their environment. According to Rahmah and Sumarwan (2018), a person's lifestyle can be seen from the behavior carried out by individuals such as activities to obtain or use goods and services, including the decision making process in determining these activities. Furthermore, Sathish (2012) states that there are 2 factors that influence a person's lifestyle, namely factors that come from within the individual (internal) and factors that come from outside (external). Internal factors, namely attitudes, experiences, and observations, personality, self-concept, motives, and perceptions. External factors explained by Nugraheni (2003) are reference groups, family, social class, and culture (Adi Sunarya, 2019).

\subsection{Customer satisfaction}

Wikhamn (2019) states that customer satisfaction is defined as an evaluation of the perceived discrepancy between previous expectations and the actual performance of the product. Customer satisfaction is basically how customers evaluate the products and services provided by the organization (Rauch, 2016). According to customer satisfaction is the customer's reaction to the state of satisfaction, and customer assessment of the level of satisfaction (Hong, 2015). Customer satisfaction is very important in today's business world because according to Kotler (2017), the ability of product and service providers to create high levels of satisfaction is very important for product differentiation and developing strong relationships with customers. According to Rita and Olievera (2019), customer satisfaction can provide benefits, including building a harmonious relationship between the company and customers, providing a good basis for repurchasing, and encouraging loyalty. According to Kotler (2017), the dimensions of customer satisfaction consist of price, quality of services provided, product quality, emotional factors, and pride in using the product.

\subsection{Buying decision}

Every consumer makes various kinds of decisions about the search, purchase, use of various products and services. Purchasing decisions are consumer decisions regarding preferences for brands in the selection (Tan, 2019). Munthiu (2009) defines a purchasing decision as a person's decision where he chooses one of several alternative options (Eshra \& Beshir, 2019). In this study, purchasing decisions are defined as a process in which consumers choose one product according to their taste to make decisions in product purchases (Amron, 2018). Kotler (2017) states that there are five stages in explaining the process by which purchasing decisions are made 
namely (1) problem recognition, which includes the introduction of needs, (2) information search, namely where consumers will buy and what to buy, (3) ) alternative evaluation, namely the stage where consumers anticipate when they do not find what they need, (4) purchasing decisions, namely actions when consumers have found what they need, (5) post-purchase behavior, namely the attitude where consumers have made a purchase. Kotler (2017) mentions three dimensions in explaining that can measure purchasing decisions, namely, benefit association, priority in buying, and frequency of purchases. As for the factors that can influence an act of purchasing decisions are individual differences that include resources, knowledge, attitudes, and environmental influences including culture, social class, family, and situation.

\subsection{Conceptual framework}

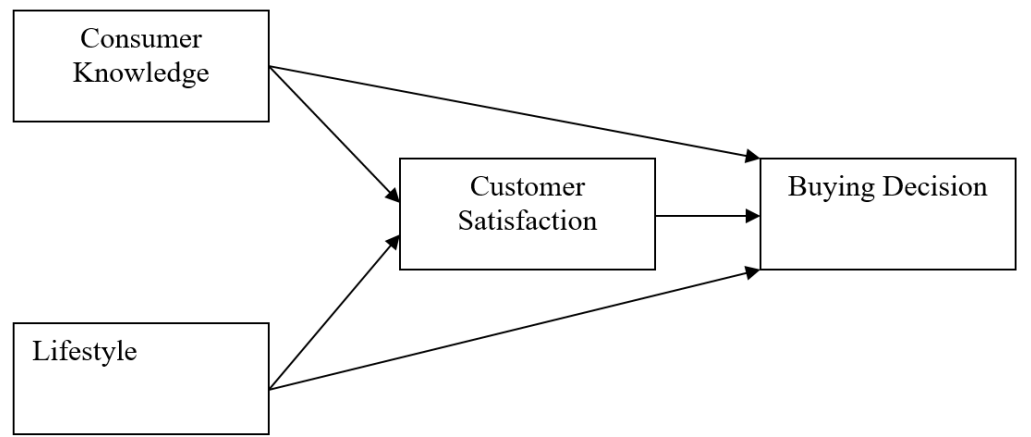

Figure 1. Relationship between knowledge variables, lifestyle, satisfaction and decisions

\section{Hypothesis Development}

\subsection{The influence of knowledge on customer satisfaction}

Because consumers tend to pay close attention to satisfaction when making purchases, usually before making these purchases, consumers find out first. According to Dierch (2017), this search leads to knowledge that can be used as a decision to act so that in the end the decision provides satisfaction for consumers. Aydiner (2019) states that consumer knowledge affects satisfaction in purchasing products or services.

H1. Consumer knowledge has an effect on customer satisfaction

\subsection{The influence of lifestyle on customer satisfaction}

Lifestyle is a person's lifestyle that is expressed through their activities, interests and opinions. According to Kotler (2017), lifestyle can show how people live, how to spend money, and how to allocate time. Rahmah (2018) states that a person's lifestyle can provide satisfaction for the person himself in purchasing a product or service.

H2. Lifestyle affects consumer satisfaction

\subsection{The influence of knowledge on purchasing decisions}

Knowledge is a person's ability that can directly or indirectly enrich someone. In determining the decisionmaking process, a person will not be separated from the knowledge he has. Paschen's research (2019) states that there is an influence between knowledge and purchasing decisions. Likewise, with Chukwuma's research (2018) that knowledge has an effect on purchasing decisions.

H3. Knowledge influences consumer purchasing decisions

\subsection{The influence of lifestyle on purchasing decisions}

Not only knowledge, lifestyle factors are also one of the factors that can influence purchasing decisions. According to Adi (2019), a person's lifestyle can form a character where this character can influence every action. Rahmah (2018) states that lifestyle factors can influence purchasing decisions. H4. Lifestyle influences consumer purchasing decisions

\subsection{The influence of knowledge and lifestyle on purchasing decisions through customer satisfaction}


Tan (2019) states that a purchase decision is an action in which consumers choose one of various alternatives based on consumer ability. This capability includes the knowledge and experience possessed by consumers themselves. Apart from this ability, Adi (2019) states that purchasing decisions are closely related to the lifestyle of consumers (Omar, 2020). This shows that knowledge and lifestyle have an impact on purchasing decisions. From the perspective of consumer experience, a decision occurs when the consumer is previously satisfied with what their needs are. This indicates that consumer satisfaction can influence consumer decisions, especially when the consumer already understands the product or service before making a purchase (Amron, 2018).

H5. Knowledge and lifestyle influence purchasing decisions through customer satisfaction.

\section{Research Methods}

This study uses a quantitative analysis approach by adopting multiple regression analysis techniques. The sample in this study was 118 respondents. The sampling technique in this study is non-probability sampling with incidental sampling. According to Sekaran (2016), incidental sampling is a sampling technique based on chance at that time which is sampled if there is a match as the sample. The data sources and data methods used in this research are observation, interviews, and questionnaires. Meanwhile, secondary and primary data used a Likert scale.

\section{Results and Analysis}

The characteristics of the respondents in this study are as follows:

Table 1. Characteristics of respondents

\begin{tabular}{cccc}
\hline No. & Gender & Total & Percentage \\
\hline 1 & Man & 39 & $30 \%$ \\
\hline 2 & Women & 79 & $70 \%$ \\
\hline & Total & 118 & $100 \%$ \\
\hline No. & Age & Total & Percentage \\
\hline 1 & $25-30$ years & 19 & $10 \%$ \\
\hline 2 & $31-35$ th & 41 & $39 \%$ \\
\hline 3 & $36-40$ th & 26 & $21 \%$ \\
\hline 4 & $41-45$ years & 21 & $19 \%$ \\
\hline 5 & $>45$ years & 11 & $11 \%$ \\
\hline & Total & 118 & $100 \%$ \\
\hline No. & Education & Total & Percentage \\
\hline 1 & Junior High & 28 & $32 \%$ \\
\hline 2 & High school & 48 & $45 \%$ \\
\hline 3 & Bachelor & 42 & $23 \%$ \\
\hline & Total & 118 & $100 \%$ \\
\hline No. & Status & Total & Percentage \\
\hline 1 & Single & 65 & $55 \%$ \\
\hline 2 & Married & 53 & $45 \%$ \\
\hline & Total & 118 & $100 \%$ \\
\hline
\end{tabular}

Source: Primary data processed in 2020

Consumer knowledge variables can certainly have an impact on a decision action. Table 1 shows that based on gender characteristics, women are more dominant with a gain of $79 \%$ when compared to men. Meanwhile, based on the characteristics of the age most were at the age of 31-35, namely 39\%. This shows that at that age many people use batik for work or other purposes. Based on education, there are more high school graduates than other graduates, namely $45 \%$. Meanwhile, based on status, unmarried people dominate more than married people, namely $55 \%$.

\subsection{Validity and reliability test results}

The results of the validity test on the variable price reasonableness ( 5 items), employee satisfaction $(5$ items) customer satisfaction ( 5 items) and service delivery ( 5 items) have a significant value> 0,235 or in other words valid. The reliability test is as follows: 
Table 2. Reliability test

\begin{tabular}{cccc}
\hline Variable & Cronbach Alpha & Critical Value & Information \\
\hline Knowledge & 0,932 & 0,60 & Reliable \\
\hline Lifestyle & 0,918 & 0,60 & Reliable \\
\hline Buying decision & 0,958 & 0,60 & Reliable \\
\hline Consumer satisfaction & 0,952 & 0,60 & Reliable \\
\hline
\end{tabular}

Source: Primary data processed in 2020

Based on the results of Table 2, it shows that the research variable has a cronbch alpha coefficient of more than 0.60 . This shows that all variables have met the reliability requirements.

Table 3. Responses to research variables

Source: Primary data processed in 2020

\begin{tabular}{ccc}
\hline Variable & Mean & Category \\
\hline Knowledge & 3,57 & Very high \\
\hline Lifestyle & 3,12 & Conducive \\
\hline Buying decision & 3,21 & High \\
\hline Consumer satisfaction & 3,72 & Very high \\
\hline
\end{tabular}

Based on Table 3, it can be concluded as follows:

a. The consumer knowledge variable has a value of 3.57 (very high), this indicates that consumers have knowledge of a product or service and have a consideration in making purchases when visiting the store where they will buy.

b. The lifestyle variable has a value of 3.12 (conducive), this shows that the lifestyle of consumers is different from one another. The lifestyle of consumers is a habit related to daily life and is influenced by social, economic and environmental levels.

c. The purchasing decision variable is 3.21 (high), this indicates that the purchase decision is the ability to buy which is based on kebutahn and desire and the benefits of what the consumer wants.

d. The consumer satisfaction variable is at a value of 3.72 (very high), this shows that customer satisfaction is a condition that is felt after purchase so that it can lead to loyalty to the product purchased. But in reality, a lot of satisfaction is influenced by other factors that are not discussed in this study.

\subsection{Hypothesis test results}

Table 4. Hypothesis test

\begin{tabular}{ccc}
\hline No. & Hypothesis & Information \\
\hline 1 & Knowledge affects customer satisfaction & proven \\
2 & Lifestyle affects consumer satisfaction & proven \\
3 & Knowledge influences purchasing decisions & proven \\
4 & Lifestyle influences purchasing decisions & proven \\
5 & Knowledge and lifestyle influence decisions through satisfaction & proven \\
\hline
\end{tabular}

Source: Primary data processed in 2020

\subsection{Equation normality test}

To find out whether the data is normally distributed or close to normal, the Kolmogrov-Smirnov (KS) statistical test can be carried out, the normality test of the data in this study uses the one-sample KolmogorovSmirnov test with the condition that asympp sig (2-tailed)> 0.05 then the data is normally distributed.

Table 5. Normality of equation (1)

\begin{tabular}{cc}
\hline One-Sample Kolmogorov-Smirnov Test & \\
\hline & Unstandardized Residual \\
\hline $\mathrm{N}$ & 100 \\
\hline
\end{tabular}


Knowledge on Batik and Lifestyle on Purchase Decisions with Satisfaction as Intervening (Case Study of Batik SME'S in Jambi City)

\begin{tabular}{ccc}
\hline Normal Parametersa,b & Mean &, 0000000 \\
\cline { 2 - 3 } & Std. Deviation & 5,08091707 \\
\hline \multirow{2}{*}{ Most Extreme Differences } & Absolute &, 074 \\
\cline { 2 - 3 } & Positive &, 039 \\
\cline { 2 - 3 } & Negative &,- 074 \\
\hline \multicolumn{2}{c}{ Test Statistic } &, 074 \\
\hline Asymp. Sig. (2-tailed) &, $200 \mathrm{c.d}$ \\
\hline
\end{tabular}
a. Test distribution is Normal.
b. Calculated from data.
c. Lilliefors Significance Correction
d. This is a lower bound of the true significance

Source: Primary data processed in 2020

Based on Table 7, the equality 1 normality test shows that the value of Asymp. Sig. (2-tailed) of 0.200> 0.05 , this means that the data in this study were normally distributed.

Table 6. Normality of equation (2)

\begin{tabular}{|c|c|c|}
\hline \multicolumn{3}{|c|}{ One-Sample Kolmogorov-Smirnov Test } \\
\hline \multirow{2}{*}{\multicolumn{2}{|c|}{$\mathrm{N}$}} & Unstandardized Residual \\
\hline & & 100 \\
\hline \multirow[t]{2}{*}{ Normal Parametersa,b } & Mean &, 0000000 \\
\hline & Std. Deviation & 4,88871262 \\
\hline \multirow[t]{3}{*}{ Most Extreme Differences } & Absolute &, 062 \\
\hline & Positive & 046 \\
\hline & Negative &,- 062 \\
\hline \multicolumn{2}{|l|}{ Test Statistic } &, 062 \\
\hline \multicolumn{2}{|c|}{ Asymp. Sig. (2-tailed) } & ,200c.d \\
\hline \multicolumn{3}{|c|}{$\begin{array}{l}\text { a. Test distribution is Normal. } \\
\text { b. Calculated from data. } \\
\text { c. Lilliefors Significance Correction } \\
\text { d. This is a lower bound of the true significance }\end{array}$} \\
\hline
\end{tabular}

Source: Primary data processed in 2020

Based on Table 8, the normality test for equation (2) shows that the Asymp. Sig. (2-tailed) of 0.200>0.05, this means that the data in this study were normally distributed.

\subsection{Multicollinearity test}

The multicolinearity test aims to test whether the regression model finds a correlation between independent (independent) variables, a good regression model should not have a correlation between the independent variables (Ghozali, 2016).

Table 7. Multicollinearity test for equation (1)

\begin{tabular}{cccc}
\hline & & \multicolumn{2}{c}{ Collinearity Statistics } \\
\cline { 3 - 4 } & Model & Tolerance & VIF \\
\hline \multirow{2}{*}{1} & (Constant) & & \\
\cline { 2 - 4 } & Knowledge & 0,971 & 1,041 \\
\cline { 2 - 4 } & Lifestyle & 0,971 & 1,041 \\
\hline
\end{tabular}

a. Dependent Variable: Consumer satisfaction

Source: Primary data processed in 2020

From Table 7, equation (1) shows that all independent variables have a tolerance value $>0.10$ and a VIF value $<10$, so that all independent variables do not have multicollinearity. 
Table 8. Multicollinearity test for equation (2)

\begin{tabular}{cccc}
\hline \multirow{2}{*}{1} & & \multicolumn{2}{c}{ Collinearity Statistics } \\
\cline { 2 - 4 } & Model & Tolerance & VIF \\
\cline { 2 - 4 } & (Constant) & & \\
\cline { 2 - 4 } & Knowledge & 0,687 & 1,436 \\
\cline { 2 - 4 } & Lifestyle & 0,810 & 1,204 \\
\cline { 2 - 4 } & $\begin{array}{c}\text { Consumer } \\
\text { satisfaction }\end{array}$ & 0,613 & 1,659 \\
\hline
\end{tabular}

a. Dependent Variable: Buying decision

Source: Primary data processed in 2020

From Table 8, equation (2) shows that all independent variables have a tolerance value $>0.10$ and a VIF value $<10$, so that all independent variables do not have multicollinearity.

\subsection{Sub-Structure Equations (1)}

Table 9. Path coefficient 1

\begin{tabular}{|c|c|c|c|c|c|c|}
\hline \multirow{2}{*}{\multicolumn{2}{|c|}{ Model }} & \multicolumn{2}{|c|}{$\begin{array}{l}\text { Unstandardized } \\
\text { Coefficients }\end{array}$} & \multicolumn{3}{|c|}{$\begin{array}{l}\text { Standardized } \\
\text { Coefficients }\end{array}$} \\
\hline & & $\mathrm{B}$ & Std. Error & Beta & $\mathrm{t}$ & Sig. \\
\hline \multirow{3}{*}{1} & (Constant) & 11,709 & 2,461 & & 4,716 & 0,000 \\
\hline & Knowledge & 0,637 & 0,102 & 0,478 & 6,066 & 0,000 \\
\hline & Lifestyle & 0,353 & 0,039 & 0,374 & 3,952 & 0,000 \\
\hline
\end{tabular}

a. Dependent Variable: Buying decision

Source: Primary data processed in 2020

The equation for the results of the path analysis that is formed is: $\mathrm{Y}=11.709+0.478 \mathrm{X} 1+0.374 \mathrm{X} 2$

1. A constant value of 11,709 means that if knowledge and lifestyle do not increase, then satisfaction will still be worth 11.609 .

2. The beta coefficient value 0.478 (positive) shows a unidirectional effect, which means that if the level of consumer knowledge increases, it will increase satisfaction by 0.478 .

3. The beta coefficient value of 0.374 (positive) shows a unidirectional influence, which means that if the level of a more attractive lifestyle will make an increase in satisfaction by 0.374 .

Table 10. The coefficient of determination of equation (1) \begin{tabular}{lllll}
\hline Model R R Square Adjusted R Square Std. Error of the Estimate & R
\end{tabular}

\begin{tabular}{lllll}
\hline 1 &, $637 \mathrm{a}$ & 0,398 & 0,385 & 5,13303 \\
\hline
\end{tabular}

a. Predictors: (Constant), Lifestyle, Knowledge

b. Dependent Variable: Consumer satisfaction

Source: Primary data processed in 2020

From Table 10, it is found that the Rsquare value of 0.398 means that $39.8 \%$ of the customer purchase interest variable is influenced by the trust and promotion variables, while the remaining $60.2 \%$ is explained by other factors not discussed in this study. Then, the error value is obtained at 0.775 .

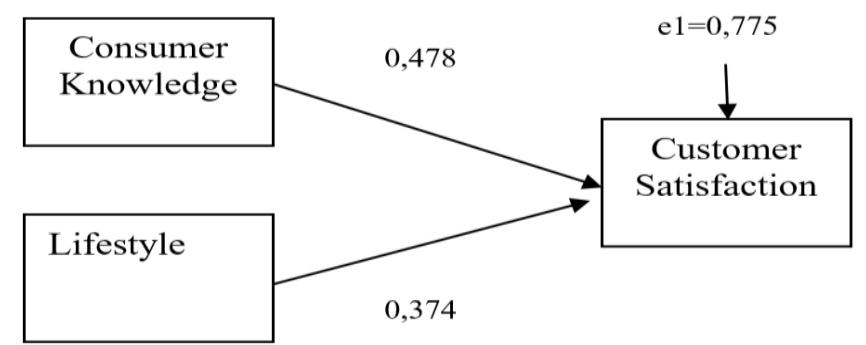

Figure 1. Line acquisition stage 1 

0.775 .

In the picture above, the following equation for the first-stage path is obtained: $\mathrm{Y}=0.478 \mathrm{X} 1+0.374 \mathrm{X} 2+$

\subsection{Sub-Structure Equations (2)}

Table 11. Path coefficient stage 2

\begin{tabular}{cccccc}
\hline & \multicolumn{4}{c}{ Unstandardized Coefficients } & \multicolumn{4}{c}{ Standardized Coefficients } \\
\cline { 2 - 6 } Model & $\mathrm{B}$ & Std. Error & Beta & $\mathrm{t}$ & Sig. \\
\hline (Constant) & 12,211 & 2,639 & & 4,626 & 0,000 \\
\hline Knowledge & 0,578 & 0,115 & 0,453 & 4,987 & 0,000 \\
\hline Lifestyle & 0,303 & 0,041 & 0,397 & 2,531 & 0,013 \\
\hline Consumer satisfaction & 0,375 & 0,098 & 0,393 & 3,902 & 0,002 \\
\hline
\end{tabular}

a. Dependent Variable: Buying decision

Source: Primary data processed in 2020

The equation for the results of the path analysis that is formed is: $\mathrm{Z}=12.211+0.453 \mathrm{X} 1+0.397 \mathrm{X} 2+$ $0.393 \mathrm{Y}$

1. A constant value of 12.211 indicates that if knowledge, lifestyle, and customer satisfaction do not change, the purchase decision will still be worth 12.211 .

2. The beta coefficient value of 0.453 (positive) shows a unidirectional effect, which means that if the level of consumer knowledge is increased, it will increase the purchasing decision by 0.453 .

3. The beta coefficient value of 0.397 (positive) shows a unidirectional effect, which means that if the level of lifestyle is increased it will make an increase in purchasing decisions by 0.397 .

4. The beta coefficient value of 0.393 (positive) shows a unidirectional effect, which means that if the level of customer satisfaction is increased, it will make an increase in purchasing decisions by 0.393 .

Table 12. Coefficient of determination of equation (2)

\begin{tabular}{lll} 
Model & R & R Square Adjusted R Square Std. Error of the Estimate \\
\hline
\end{tabular}

$\begin{array}{lllll}1 & \text {,721a } & 0,539 & 0,504 & 4,96451\end{array}$

a. Predictors: (Constant), Purchase Interest, Promotion, Trust

b. Dependent Variable: Purchase Decision

Source: Primary data processed in 2020

From Table 12, it is obtained that the Rsquare value is 0.539 which means that $53.9 \%$ of the purchasing decision variable is influenced by the variables of knowledge, lifestyle, and customer satisfaction, while the remaining $46.1 \%$ is explained by other factors not included in this research model. Then the error value is obtained at 0.678 .

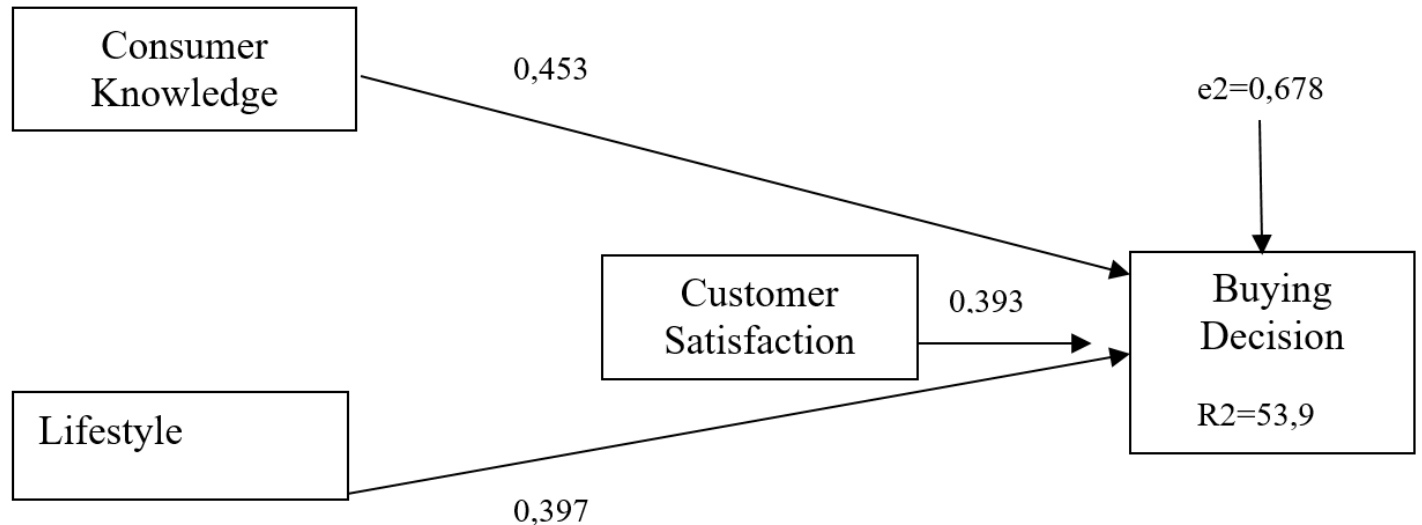

Figure 2. Path analysis stage 2

Based on Figure 2, the second stage path equation, the following equation is obtained: $\mathrm{Z}=0.453 \mathrm{X} 1+$ $0.397 \mathrm{X} 2+0.393 \mathrm{Y}+0.678$. The causal relationship between variables as a whole from the results of statistical tests or a combination of the first and second equations can be seen in the following figure: 


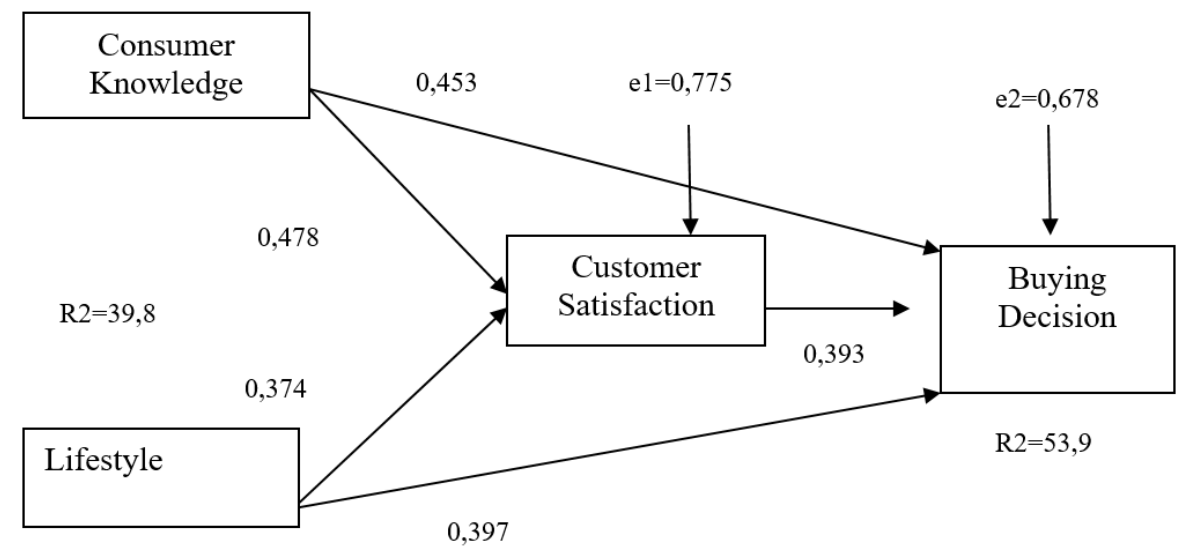

Based on the path diagram in the Figure above. Then, it can be calculated the amount of direct effect, indirect effect and total effect between variables. According to Ghozali (2016), to find out the indirect effect of a path by multiplying the indirect coefficient.

\section{Discussion}

\subsection{The effect of knowledge on customer satisfaction}

Hypothesis test results indicate that consumer knowledge has a positive and significant effect on customer satisfaction. This means that the higher the level of consumer knowledge, the higher the trustworthiness of the customer obtained from a purchase. The decision to buy something is certainly based on the knowledge they have in order to get satisfaction for consumers. Because consumers believe and believe that purchases based on their knowledge can have an influence on satisfaction. The results of this study are in line with research conducted by Dierch (2017) which states that consumer knowledge has an influence on satisfaction.

\subsection{The effect of lifestyle on customer satisfaction}

The results of hypothesis testing prove that lifestyle has a positive and significant effect on consumer satisfaction. This means that the higher the lifestyle of the promotional consumer, the higher the satisfaction received through the purchase of a product or service. Rahmah (2018) states that the consumer's lifestyle which consists of attitudes and behavior affects the satisfaction he purchases.

\subsection{The effect of satisfaction on purchasing decisions}

The results of hypothesis testing prove that customer satisfaction has an influence on purchasing decisions. This shows that the higher the consumer is satisfied with a purchase, the higher the purchase decision will be. This is as stated by Omar (2020) that customer satisfaction has an influence on purchasing decisions.

\subsection{The effect of knowledge on purchasing decisions}

The results of hypothesis testing prove that consumer knowledge has a positive and significant effect on purchasing decisions. This means that the higher the level of consumer knowledge, the higher the purchasing decision. Adi (2019) concluded that the higher the consumer's knowledge, the higher the purchase rate. These results are supported by research by Amron (2018) which states that knowledge has an effect on purchasing decisions.

\subsection{The influence of lifestyle on purchasing decisions}

The results of hypothesis testing prove that the promotional lifestyle has a positive and significant effect on purchasing decisions. This means that the more the consumer's lifestyle, the higher the purchasing decision. This lifestyle attracts and encourages many consumers to buy products. This is supported by Rahmah (2018) which states that lifestyle factors can influence purchasing decisions

\subsection{The influence of knowledge and lifestyle on purchasing decisions through customer satisfaction}


The results of hypothesis testing prove that the mediating variable, namely customer satisfaction, is able to mediate the effect of knowledge and lifestyle on purchasing decisions. The results of this study are in line with Chukwuma (2018) which states that knowledge influences purchasing decisions, lifestyle affects purchasing decisions, satisfaction affects purchasing decisions, and satisfaction also mediates the knowledge and lifestyle variables on purchasing decisions.

\section{Conclusion}

The consumer's knowledge of a product is critical to a decision to be made. But in addition to knowledge of lifestyle factors, these factors can shape consumer behavior and attitudes in making a purchase. Based on the knowledge they have, a purchase can provide satisfaction for consumers, especially Batik in Jambi City. However, along with the development and emergence of $\mathrm{Y}$ and Millennial generations, now Batik itself is a lifestyle that can provide its own satisfaction for its wearers. As for the suggestions that can be given in this study, SMEs, especially Batik in Jambi City, should always provide knowledge to consumers in order to become one of the bases on which consumers can make purchases. And by continuing to improve the batik motifs themselves which are adjusted to the models and colors according to the tastes of the consumers themselves.

\section{References}

1. Adi Surya Pranantha, K., \& Sri Subawa, N. (2019). Lifestyle Marketing, Brand Personality, Brand Image, Customer Satisfaction, Customer Loyalty dan Impulse Buying. Jurnal Manajemen Bisnis, 16(4), 116.

2. Amron, A. (2018). The Influence of Brand Image, Brand Trust, Product Quality, and Price on the Consumer's Buying Decision of MPV Cars. European Scientific Journal, 14(13), 228.

3. Aziz, N. N. A., \& Samad, S. (2016). Innovation and competitive advantage: Moderating effects of firm age in foods manufacturing SMEs in Malaysia. Procedia Economics and Finance, 35, 256-266.

4. Aydiner, A. S., Tatoglu, E., Bayraktar, E., \& Zaim, S. (2019). Information system capabilities and firm performance: Opening the black box through decision-making performance and business-process performance. International Journal of Information Management, 47, 168-182.

5. Chen, C.J.; Huang, J.W.; Hsiao, Y.C. Knowledge Management and Innovativeness: The Role of Organizational Climate and Structure. Int. J. Manpow., 2010, 31, 848-870.

6. Chukwuma, A. I., Ezenyilimba, E., \& Agbara, N. O. (2018). Effect of product packaging on the sales volume of small and medium scale bakery firms in South East Nigeria. International Journal of Academic Research in Business and Social Sciences, 8(6), 988-1001.

7. Diehr, G., \& Wilhelm, S. (2017). Knowledge marketing: How can strategic customers be utilised for knowledge marketing in knowledge-intensive SMEs? Knowledge Management Research and Practice, 15(1), 12-22.

8. Dedahanov, A.T.; Bozorov, F.; Sung, S.H. Paternalistic Leadership and Innovative Behavior: Psychological Empowerment as a Mediator. Sustainability 2019, 11, 1770.

9. Eugine, T, 2020. Green packaging and green advertising as precursors of of competitive advantage and business performance among manufacturing small and medium enterprises in South Africa. Cogent Business \& Management, 7(1), 1719586.

10. Eshra, N., \& Beshir, N. (2019). Effect of Consumer Attitude towards SMS Advertising and Demographic Features on Egyptian Consumers Buying Decision. Journal of Marketing Management, 7(2), 2333-6099.

11. Gao, J., \& Bernard, A. (2018). An overview of knowledge sharing in new product development. The International Journal of Advanced Manufacturing Technology, 94(5), 1545-1550

12. Horvart, A and Granato, 2019. Understanding consumer data use in new product development and the product life cycle in European food firms - An empirical study. Food Quality and Preference (2019) 76 20-32.

13. Hong, Y and Chang (2015) Firm's knowledge creation structure for new product development. Cogent Business \& Management. Vol 2 issue 1.

14. Munthiu, M.-C. (2009). The buying decision process and types of buying decision behaviour. Sibiu Alma Mater University Journals, 2(4), 27-33.

15. Omar, A. M., \& Atteya, N. (2020). The Impact of Digital Marketing on Consumer Buying Decision Process in the Egyptian Market. International Journal of Business and Management, 15(7), 120.

16. Rita, P., Oliveira, T., \& Farisa, A. (2019). The impact of e-service quality and customer satisfaction on customer behavior in online shopping. Heliyon, 5(10), e02690.

17. Rauch, E and Patrick, D, (2016) The way from Lean Product Development (LPD) to Smart Product Development (SPD). Procedia CIRP, 50, 26-31. 
18. Rakic, M., \& Rakic, B. (2015). Sustainable lifestyle marketing of individuals: The base of sustainability. Amfiteatru Economic, 17(40), 891-908.

19. Rahmah, K., Sumarwan, U., \& Najib, M. (2018). The Effect of Brand Equity, Marketing Mix, And Lifestyle to Purchase Decision at Maxx Coffee, Bogor. Journal of Consumer Sciences, 3(2), 01-15.

20. Tan, C. N. L., Ojo, A. O., \& Thurasamy, R. (2019). Determinants of green product buying decision among young consumers in Malaysia. Young Consumers, 20(2).

21. Paschen, J., Kietzmann, J., \& Kietzmann, T. C. (2019). Artificial intelligence (AI) and its implications for market knowledge in B2B marketing. Journal of Business and Industrial Marketing, 34(7), 14101419.

22. Sathish, S., \& Rajamohan, a. (2012). Consumer behaviour and lifestyle marketing. International Journal of Marketing, Financial Services \& Management Research, 1(10), 152-166.

23. Wikhamn, W. (2019). Innovation, sustainable HRM and customer satisfaction. International Journal of Hospitality Management, 76, 102-110.

24. Zhang, J and Cao, (2018). Contract and Product Quality in Platform Selling. European Journal of Operational Research, 272(3), 928-944. 